Pobrane z czasopisma Annales H - Oeconomia http://oeconomia.annales.umcs.pl Data: 26/04/2023 13:33:06

DOI:10.17951/h.2018.52.1.161

\begin{tabular}{lcl}
\hline \multicolumn{1}{c}{ A N N A L E S } \\
UNIVERSITATIS MARIAE CURIE-SKŁODOWSKA \\
LUBLIN - POLONIA \\
VOL. LII, 1 & SECTIO H \\
\hline
\end{tabular}

University of Szczecin. Faculty of Economics and Management

\author{
DOROTA SKALA
}

dskala@wneiz.pl

\title{
Loan Growth Strategies and Income Smoothing in Central European Banks ${ }^{1}$
}

Strategie wzrostu kredytów a wygładzanie dochodów w bankach Europy Centralnej

Keywords: income smoothing; Central European banks; loan growth

Słowa kluczowe: wygładzanie dochodów; banki Europy Centralnej; wzrost kredytów

JEL Code: G21; G31

\section{Introduction}

Income smoothing is a widely spread phenomenon amongst both developed and developing country banks. Income smoothing is performed through adjusting levels of annual loan loss reserves, not only to the quality of the loan portfolio but also to the pre-reserve level of income. In such a case, abundant reserves are made when earnings are high, to allow for diminished reserve burdens in more difficult times [Cavallo, Majnoni, 2002; Perez, Salas-Fumás, Saurina, 2008; Bikker, Metzemakers, 2005; Fonseca, González, 2008].

Various aspects of the income smoothing process are analysed in the literature. Numerous researchers study the role of income smoothing (seen as forward-looking

1 Research funded by the National Science Centre, Poland, within the research project No. 2015/ 17/D/HS4/03118. 
reserves) in decreasing procyclicality of capital regulations [Cavallo, Majnoni, 2003; Fillat, Montoriol-Garriga, 2010; Bikker, Metzemakers, 2005]. Bouvatier, Lepetit and Strobel [2014] incorporate regulatory- and corporate governance aspects into income smoothing, while Quaglieriello [2007] and Olszak and Pipień [2014] analyse cyclicality of bank reserves and their link with the business cycle. The bulk of the existing work relates to developed country financial institutions, stemming either from the US or Western Europe. Studies on Central European commercial banks are less numerous and to date have been centred around the question of cyclicality of loan loss provisions [e.g. Skała, 2015]. An important area, less covered in the literature, relates to the profile of a bank that decides to use income smoothing. In this paper, we aim to analyse income smoothing from the point of view of bank loan growth. We want to determine if a difference in the expansion strategy of a bank may affect its income smoothing policies. Banks that grow organically are likely to shape their reserve making policies differently than banks that witness aggressive expansion, including merger and acquisition activities.

Income smoothing in banks is covered in two main literature areas. Firstly, income smoothing is considered as a form of earnings management, where managers and/or shareholders introduce discretionary changes to the earnings stream, in order to pursue specific goals. Earnings management is well-documented for the non-financial sector and is connected to incentives of managers and/or shareholders [Healy, Wahlen, 1999; Goel, Thakor, 2003]. This rationale underlies studies regarding the discretionary part of income smoothing in banks. Bushman and Williams [2012] prove that forward-looking reserves that are aimed to diminish variability of bank income have adverse effects on bank risk and market discipline.

Secondly, income smoothing through loan loss provisions in banks may constitute an element of prudent bank credit policy. The specific character of bank activities, mainly pertaining to asymmetric information problems, implies that there is always a part of credit portfolio that will become non-performing. Hence, prudent banks with adequate credit history are likely to create forward-looking reserves, to account for future deterioration in asset quality. This process is exacerbated by the fact that an increased proportion of loans is likely to become non-performing during an economic crisis, which in turn correlates with periods of weak earnings of banks. In such a way, income smoothing is closely linked with forward-looking reserve policies. In macroeconomic downturns, banks are experiencing pressure on their capital levels and tend to limit their loan supply. Such a credit crunch is unfavourable to the whole economy and delays economic recovery. If there is an increased pressure on earnings stemming from higher reserves, the credit crunch may be exacerbated. Hence, forward-looking reserves - seen as income smoothing - that are diminishing such pressure, may, in fact, be welfare-improving [Laeven, Majnoni, 2003]. Positive effects of transparent reserves accounting for future loan losses are shown by Bushman and Williams [2012], who however indicate that the adverse result coming from discretionary, managerial incentives may outweigh such gains. 


\section{Methodology and data}

In our study, we use data for 216 commercial banks from 11 Central European countries in the period 2003-2014². Our sample includes the following European Union countries: Bulgaria, Croatia, Czech Republic, Estonia, Hungary, Latvia, Lithuania, Poland, Romania, Slovakia, Slovenia. All financial data for banks is taken from the Bureau Van Dijk Banscope database. Due to outlying observations and potential faulty inputs, we winsorise all the variables at 1/99 percentile levels. The final sample includes 1384 bank-year observations. The split of observations by country is presented in Table 1.

The aim of our work is to analyse income smoothing from the point of view of loan expansion. Central European banking sectors have been developing rapidly over the past 20 years, but there have been important differences in growth strategies between particular institutions. The existence of income smoothing and procyclicality of banks in the region have been empirically confirmed [Skała, 2015]. Our analysis allows to establish if there is homogeneity in this group in income smoothing behaviour. More precisely, we analyse if high-growth banks engage in income smoothing in a different manner than their low-growth peers. In this context, we consider two possible scenarios.

Table 1. Data by country, for the total sample period

\begin{tabular}{|l|r|r|r|}
\hline \multicolumn{1}{|c|}{ Country name } & \multicolumn{1}{c|}{ Freq. } & Percent & \multicolumn{1}{c|}{ Cum. } \\
\hline Bulgaria & 141 & 10.19 & 10.19 \\
\hline Croatia & 189 & 13.66 & 23.84 \\
\hline Czech Republic & 151 & 10.91 & 34.75 \\
\hline Estonia & 42 & 3.03 & 37.79 \\
\hline Hungary & 86 & 6.21 & 44.00 \\
\hline Latvia & 126 & 9.10 & 53.11 \\
\hline Lithuania & 78 & 5.64 & 58.74 \\
\hline Poland & 191 & 13.80 & 72.54 \\
\hline Romania & 136 & 9.83 & 82.37 \\
\hline Slovakia & 107 & 7.73 & 90.10 \\
\hline Slovenia & 137 & 9.90 & 100.00 \\
\hline Total & 1384 & 100.00 & \\
\hline
\end{tabular}

Source: Bankscope, author's calculations.

On one hand, income smoothing is an inter-temporal process that entails longerterm planning. Banks create higher reserves in one period in order to diminish reserves in the future and this process is likely to bring expected results only when no

2 The raw sample includes all commercial, savings-, cooperative- and real-estate banks of the region that are in the Bankscope database. Some banks are excluded due to lacking financial data, especially on the credit risk side. 
large differences appear in the size of the underlying loan portfolio. When there is an acquisition, or the bank is taken over, the smoothing cycle may be stopped. Furthermore, banks planning acquisitions are less likely to engage in income smoothing, as future earnings from merged entities are more difficult to predict. In such a case, high-growth banks should demonstrate lower income smoothing inclinations.

On the other hand, well-performing banks that are preparing to acquire another institution accumulate funds for the expected takeovers, which may be partly channelled through more abundant loan loss reserves. In such a case, smoothing may, in fact, be stronger. In addition, when the merger takes place and initial costs are high, reserves are likely to be released to ease the pressure on the bottom line result, which exacerbates the smoothing process. In consequence, high-growth banks may have incentives to engage in income smoothing more than their low growth peers.

In order to test the income smoothing behaviour of the two groups of banks, we use the standard income smoothing equation. It takes the following form:

$$
L L P_{i, t}=\alpha+\beta_{1} \text { Income }_{i, t}+\beta_{2} \text { Bank control variables }_{i, t}+v_{i}+\varepsilon_{i, t}
$$

In Equation (1), the dependent variable is Loan Loss Provisions (LLP) for bank $i$ and year $t$, which depicts the annual level of loan loss reserves, created through the bank's profit and loss statement. The main explanatory variable is Income, which is the pre-provisioning level of income for bank $i$ and year $t$. Both LLP and Income are scaled by previous year's assets. Income smoothing is detected if there is a positive and statistically significant relation between LLP and Income, implying that banks create higher provisions when their revenues peak. Bank control variables include a standard set of variables that reflect the intrabank standing, such as the size of the bank (Bank Size), its capital levels (Equity), its credit risk (Non-Performing Loans NPL) and reserve levels (Loan Loss Reserves - LLR), and credit intensity (Loans to Assets). $v_{\mathrm{i}}$ represents fixed effects, which are constant for a given bank throughout the period and may reflect such traits as bank governance structures or bank culture. In order to control for country-specific traits and potential one-off events during the course of our sample period, such as changes in the macroeconomic standing and/or regulatory framework, we include country- and time-fixed effects. All estimations are performed in a static, panel data fixed effects setting.

We aim to verify if the process of income smoothing may be determined by loan growth. The control variable of loan growth appears in empirical studies of income smoothing [Bouvatier, Lepetit, Strobel, 2014; Fonseca, González, 2008], but its sign and statistical significance varies. This may be due to a large discrepancy in the size of observed loan expansion rates at various banks. This is especially important in developing country banks, which are more vulnerable to macroeconomic fluctuations and their loan expansion and contraction rates may be more visible. In our sample, loan growth displays high fluctuations, although the most extreme values have been eliminated through the winsorising process (Table 2). 
In consequence, in order to determine whether loan growth strategies affect income smoothing, we estimate Equation (1) on two subsamples of banks, Low growth banks and High growth banks. We calculate the average loan growth rate per bank, using the total period. On the basis of this rate, we perform a 50 percentile division, placing banks above the median in the High growth group and the remaining banks in the Low growth group. The descriptive statistics for the two groups are presented in Table 2.

Table 2. Main variables in Low growth banks and High growth banks subsamples

\begin{tabular}{|l|r|r|r|r|r|r|r|r|r|r|}
\hline & \multicolumn{5}{|c|}{ Low growth banks } & \multicolumn{4}{c|}{ High growth banks } \\
\hline \multicolumn{1}{|c|}{ Variable } & Obs & Mean & $\begin{array}{c}\text { Std. } \\
\text { Dev. }\end{array}$ & Min & Max & Obs & Mean & $\begin{array}{c}\text { Std. } \\
\text { Dev. }\end{array}$ & Min & Max \\
\hline LLP & 753 & 1.13 & 1.61 & -1.71 & 8.45 & 631 & 1.22 & 1.64 & -1.71 & 8.45 \\
\hline Income & 753 & 1.82 & 1.90 & -8.66 & 12.04 & 631 & 1.97 & 2.19 & -8.66 & 12.04 \\
\hline NPL & 753 & 11.67 & 11.60 & 0.14 & 65.97 & 631 & 11.52 & 12.45 & 0.12 & 65.97 \\
\hline Lgr & 753 & 6.77 & 19.35 & -45.81 & 136.19 & 631 & 24.55 & 47.14 & -45.81 & 319.09 \\
\hline LLR & 753 & 6.32 & 5.21 & 0.09 & 25.76 & 631 & 5.43 & 5.30 & 0.09 & 25.76 \\
\hline Loans/Assets & 753 & 63.12 & 14.29 & 9.09 & 95.28 & 631 & 58.54 & 18.06 & 6.90 & 95.28 \\
\hline Equity & 753 & 9.98 & 4.40 & 1.60 & 46.34 & 631 & 10.97 & 5.16 & 1.60 & 46.34 \\
\hline Size & 753 & 14.76 & 1.46 & 9.71 & 17.88 & 631 & 14.09 & 1.54 & 9.97 & 17.49 \\
\hline
\end{tabular}

Notes: LLP - loan loss provisions, level of reserves created through the income statement, relative to total assets in $t-1$; Income - pre-provisioning income relative to total assets in $t-1$; NPL - non-performing loans to total loans; $L g r$ nominal growth of client loans in year $t$ relative to client loans in year $t-1$; LLR - level of loan loss reserves on the asset side; Loans/Assets - share of client loans in total assets; Equity - level of total equity relative to assets from $t-1$; Size - natural logarithm of total assets.

The mean values of main variables used in our regression analysis shown in Table 2 differ between the two loan growth subsample groups. Banks with aggressive growth are slightly smaller and their loan portfolios take up a visibly lower share of total assets. Although their loan portfolio quality is similar to that of their peers', they have lower loan loss reserves, despite the fact that they make on average slightly higher loan loss provisions. However, an increased level of equity may compensate for the lower reserves. The analysis of means does not fully demonstrate differences in credit policies between banks from high- and low-growth subsamples. Hence, the regression analysis is necessary.

\section{Results}

The results of estimating Equation (1) on the total sample and then on two subsamples of banks, as divided by average loan growth, are shown in Table 3.

The results in Specification 1 depict income smoothing for the total sample of banks. The positive and statistically significant relation between Income and LLP demonstrates that overall banks in our sample use loan loss provisions to smooth income, making higher reserves when income increases. Results on estimating Equation (1) on subsamples bring a more diverse picture. 
Pobrane z czasopisma Annales H - Oeconomia http://oeconomia.annales.umcs.pl Data: 26/04/2023 13:33:06

Table 3. Income smoothing in Low growth and High growth banks

\begin{tabular}{|l|c|c|c|}
\hline & Total sample & Low growth banks & High growth banks \\
\hline & 1 & 2 & 3 \\
\hline Income & $0.1226^{* * *}$ & $0.1381^{* * *}$ & $0.0908^{*}$ \\
\hline & {$[0.033]$} & {$[0.049]$} & {$[0.054]$} \\
\hline Loan growth & 0.0001 & -0.0036 & $-0.0034^{*}$ \\
\hline Non-performing loans & {$[0.001]$} & {$[0.004]$} & {$[0.002]$} \\
\hline & $0.0416^{* * *}$ & $0.0792^{* * *}$ & 0.0082 \\
\hline LLR & {$[0.006]$} & {$[0.009]$} & {$[0.009]$} \\
\hline & $-0.0642^{* * *}$ & $-0.0683^{* * *}$ & $-0.0929^{* * *}$ \\
\hline Loans/assets & {$[0.014]$} & {$[0.021]$} & {$[0.021]$} \\
\hline & $0.0118^{* *}$ & $0.0258^{* * *}$ & -0.0042 \\
\hline Equity & {$[0.005]$} & {$[0.007]$} & {$[0.010]$} \\
\hline & $-0.0782^{* * *}$ & $-0.0979^{* * *}$ & -0.034 \\
\hline Size & {$[0.013]$} & {$[0.019]$} & {$[0.022]$} \\
\hline & $-0.4636^{* * *}$ & 0.1064 & -0.1795 \\
\hline No. of observations & {$[0.159]$} & {$[0.269]$} & {$[0.271]$} \\
\hline No. of banks & 1384 & 753 & 631 \\
\hline Adjusted R-squared & 216 & 108 & 108 \\
\hline
\end{tabular}

Notes: LLP - loan loss provisions, level of reserves created through the income statement, relative to total assets in $t-1$; Income - pre-provisioning income relative to total assets in $t-1$; NPL - non-performing loans to total loans; $L g r$ nominal growth of client loans in year $t$ relative to client loans in year $t-1$; LLR - level of loan loss reserves on the asset side; Loans/Assets - share of client loans in total assets; Equity - level of total equity relative to assets from $t-1$; Size - natural logarithm of total assets; numbers in brackets show standard errors, ***, ** and * denote significance levels of $1 \%, 5 \%$ and $10 \%$ respectively.

Banks with a moderate pace of expansion (Specification 2) are shown to mirror the results found for the total sample and those reported in the literature. Income smoothing is present through the positive relation between LLP and Income. The size of the coefficient is larger than in the total sample. Moderately growing banks decide on reserves depending on the level of non-performing loans and the sensitivity of provisions as a function of NPL is much larger than in the total sample. When existing loan loss reserves (on the asset side) and capital levels are high, loan loss provisions are more limited. Again, these results are consistent with conclusions from the income smoothing literature.

On the other hand, banks that represent aggressive loan growth are found to use loan loss provisions to smooth income to a much lesser extent (Specification 3). In addition, the coefficient is on the verge of statistical significance. In this case, loan loss provisions depend primarily on the level of existing reserves, but only on the asset side (LLR). There is no link between bank equity levels and new loan loss provisions. Furthermore, the level of non-performing loans does not affect loan loss provisions, which reflects a somewhat lax approach to credit risk management. This implies that the rapid pace of growth, possibly connected with merger and acquisition activities, breaks the connection between loan loss provisions and loan quality. In such conditions 
income smoothing also strongly decreases, which may stem from unpredictability in future revenue streams.

Nonetheless, it is possible that relying on average loan growth of banks in a multi-country setting is not sufficient. Some banking sectors may experience higher boosts in loans and thus our results may not demonstrate the full dynamics. In order to study this further, we divide our total sample according to the fluctuations in loan growth by country. The two resulting subsamples ("Above average per country" and "Below average per country") represent expansion leaders and slow-growers in their respective markets. Results of estimating Equation (1) on these two subsamples are presented in Table 4.

Table 4. Income smoothing in banks with above- and below median growth in local markets

\begin{tabular}{|l|c|c|c|}
\hline & Total sample & $\begin{array}{c}\text { Below average per } \\
\text { country }\end{array}$ & $\begin{array}{c}\text { Above average per } \\
\text { country }\end{array}$ \\
\hline & 1 & 2 & 3 \\
\hline Income & $0.1226^{* * *}$ & $0.2208 * * *$ & $0.0790^{*}$ \\
\hline & {$[0.033]$} & {$[0.062]$} & {$[0.042]$} \\
\hline Loan growth & 0.0001 & -0.0028 & $-0.0058^{* *}$ \\
\hline & {$[0.001]$} & {$[0.002]$} & {$[0.003]$} \\
\hline Non-performing loans & $0.0416^{* * *}$ & $0.0634 * * *$ & $0.0517 * * *$ \\
\hline & {$[0.006]$} & {$[0.010]$} & {$[0.007]$} \\
\hline LLR & $-0.0642^{* * *}$ & $-0.1340 * * *$ & -0.027 \\
\hline & {$[0.014]$} & {$[0.024]$} & {$[0.018]$} \\
\hline Loans/assets & $0.0118^{* *}$ & 0.0000 & $0.0246 * * *$ \\
\hline & {$[0.005]$} & {$[0.012]$} & {$[0.006]$} \\
\hline Equity & $-0.0782^{* * *}$ & $-0.0411 *$ & $-0.0880^{* * *}$ \\
\hline & {$[0.013]$} & {$[0.024]$} & {$[0.017]$} \\
\hline Size & $-0.4636^{* * *}$ & -0.429 & 0.1919 \\
\hline & {$[0.159]$} & {$[0.335]$} & {$[0.215]$} \\
\hline No. of observations & 1384 & 438 & 946 \\
\hline No. of banks & 216 & 80 & 136 \\
\hline Adjusted R-squared & 0.225 & 0.2393 & 0.3596 \\
\hline & & & \\
\hline
\end{tabular}

Notes: LLP - loan loss provisions, level of reserves created through the income statement, relative to total assets in $t-1$; Income - pre-provisioning income relative to total assets in $t-1$; NPL - non-performing loans to total loans; $L g r-$ nominal growth of client loans in year $t$ relative to client loans in year $t-1$; LLR - level of loan loss reserves on the asset side; Loans/Assets - share of client loans in total assets; Equity - level of total equity relative to assets from $t-1$; Size - natural logarithm of total assets; numbers in brackets show standard errors, ***, ** and $*$ denote significance levels of $1 \%, 5 \%$ and $10 \%$ respectively.

The outcome of using country averages confirms and strengthens our previous results. When we differ banks according to average country loan growth, banks that are least aggressive show the strongest inclinations to apply income smoothing. The difference in the size of coefficients is much larger, indicating that it is the banks with organic growth that drive income smoothing in the total sample. 


\section{Conclusions}

In this paper, we have shown that income smoothing in Central European banks is a process that may be a function of expansion strategies of a particular bank. In financial institutions that pursue organic growth, income smoothing is stronger and more stable than in aggressively developing banks, which are (most likely) engaged in merger and acquisition activities. Mergers frequently involve unexpected costs, such as additional reserves that have to cover non-performing loans surfacing after a thorough examination of the acquired bank's loan portfolio. This implies that a merged entity's income stream is more difficult to predict and hence more challenging to smooth. The effect is particularly visible when we account for market leaders and slow-growers on national markets (rather than in larger regions). The latter are most inclined to use loan loss provisions to smooth their income streams. We stipulate that this is due to the fact that income smoothing is - by definition - a multi-period process, where the steady portfolio growth and its predictable quality in the future are important factors in the smoothing process. When banks expand rapidly, particularly through acquisitions, forward-planning is made difficult and income streams are not easily managed. Rapid credit growth is frequently connected with problems in future asset quality and reserves have to accommodate such changes. Banks that grow organically are able to more precisely plan both their loan portfolios and resulting deteriorations, as well as revenue streams. In consequence, they may create reserves in a consistently anticyclical manner, notwithstanding the motivation - stemming from managerial/shareholder incentives or prudent credit policy - that underlies the income smoothing process.

\section{Bibliography}

Bikker J.A., Metzemakers P.A.J., Bank provisioning behaviour and procyclicality, “Journal of International Financial Markets, Institutions and Money" 2005, Vol. 15(2),

DOI: https://doi.org/10.1016/j.intfin.2004.03.004.

Bouvatier V., Lepetit L., Strobel F., Bank income smoothing, ownership concentration and the regulatory environment, "Journal of Banking \& Finance" 2014, Vol. 41,

DOI: https://doi.org/10.1016/j.jbankfin.2013.12.001.

Bushman R.M., Williams C.D., Accounting discretion, loan-loss provisioning and discipline of banks' risk-taking, "Journal of Accounting \& Economics" 2012, Vol. 54(1),

DOI: https://doi.org/10.1016/j.jacceco.2012.04.002.

Cavallo M., Majnoni G., Do banks provision for bad loans in good times? Empirical evidence and policy implications, [in:] R.M. Levich, G. Majnoni, C. Reinhart (eds.), Ratings, Rating Agencies and the Global Financial System, Kluwer Academic Publishers, Boston 2002,

DOI: https://doi.org/10.1007/978-1-4615-0999-8_19.

Fillat J.L., Montoriol-Garriga J., Addressing the pro-cyclicality of capital requirements with a dynamic loan loss provision system, Federal Reserve Bank of Boston Working Paper, 2010, QAU 10-4. 
Fonseca A.R., González F., Cross-country determinants of bank income smoothing by managing loan-loss provisions, "Journal of Banking \& Finance" 2008, Vol. 32(2),

DOI: https://doi.org/10.1016/j.jbankfin.2007.02.012.

Healy P.M., Wahlen J.M., A review of the earnings management literature and its implications for standard setting, “Accounting Horizons” 1999, Vol. 13(4), DOI: https://doi.org/10.2308/acch.1999.13.4.365.

Goel A.M., Thakor A.V., Why do firms smooth earnings?, “Journal of Business” 2003, Vol. 76(1), DOI: https://doi.org/10.1086/344117.

Laeven L., Majnoni G., Loan-loss provisioning and economic slowdowns: too much, too late?, "Journal of Financial Intermediation" 2003, Vol. 12(2), DOI: https://doi.org/10.1016/S1042-9573(03)00016-0.

Olszak M., Pipień M., Cross-country linkages as determinants of procyclicality of loan loss provisions, "European Journal of Finance" 2014, Vol. 22(11).

Pérez D., Salas-Fumás V., Saurina J., Earnings and capital management in alternative loan-loss provision regulatory regimes, "European Accounting Review" 2008, Vol. 17(3),

DOI: https://doi.org/10.1080/09638180802016742.

Quagliariello M., Banks'riskiness over the business cycle: A panel analysis on Italian intermediaries, “Applied Financial Economics" 2007, Vol. 17(2), DOI: https://doi.org/10.1080/09603100500486501.

Skała D., Saving on a rainy day? Income smoothing and procyclicality of loan-loss provisions in Central European banks, "International Finance" 2015, Vol. 18(1),

DOI: https://doi.org/10.1111/1468-2362.12058.

\section{Strategie wzrostu kredytów a wygładzanie dochodów w bankach Europy Centralnej}

W pracy analizowany jest proces wygładzania dochodów w bankach Europy Centralnej w kontekście strategii ekspansji banków. Wykorzystując dane 216 banków z okresu 2003-2014, wykazano, że wygładzanie dochodów jest strategią wykorzystywaną przede wszystkim przez instytucje finansowe o niskim tempie wzrostu. Wyniki te są szczególnie widoczne, gdy brane jest pod uwagę relatywne tempo wzrostu kredytów banku na rynku krajowym. Banki o wysokim tempie wzrostu, z których część zaangażowana jest w procesy fuzji i przejęć, prawdopodobnie posiadają mniej przewidywalne strumienie dochodów, wolumeny kredytów i jakość kredytów. Ze względu na długoterminowy charakter wygładzania dochodów, brak przewidywalności może utrudniać politykę tworzenia rezerw uwzględniającą przyszłe wydarzenia.

\section{Loan Growth Strategies and Income Smoothing in Central European Banks}

In this paper, we analyse the process of income smoothing in Central European banks in the context of expansion strategies of banks. Using a sample of 216 banks in the period 2003-2014, we demonstrate that income smoothing is a strategy most pursued by low-growth financial institutions. This result is particularly visible when the relative expansion rate at local markets is taken into account. High-growth banks are likely to have less foreseeable income streams, loan volumes and loan quality. As income smoothing is a longterm process, the lack of predictability could make forward-making reserve policies more challenging. 